\title{
Morale in Battle - the Medical and the Military
}

\author{
- Field Marshal Lord Carver \\ GCB, CBE, DSO, MC, Former Chief of the Defence Staff
}

\begin{abstract}
Lecture to the United Services Section of the Royal Society of Medicine given at the Royal Army Medical College, Millbank, London, on 9th June 1988.
\end{abstract}

When the previous Surgeon-General, Sir Cameron Moffat, invited me to give this lecture, I had just finished writing a book about the development of the armed forces of the major military nations in the 20th century, and in doing so had become more aware of the great changes that have occurred during this century in attitudes to death, injury, disease and war. At the beginning of the century, the possibility of death at an early age was still something that was accepted as part of the inevitable pattern of life, whether it occurred through disease, accidental injury or war. War itself was even regarded in many countries, including our own at least as late as 1916, as ennobling. It is almost inconceivable to think of a young man today writing about going to war in the terms in which Rupert Brooke did in 1914 in his poem 'Peace'.

\footnotetext{
'Now, God be thanked Who has matched us with His hour, And caught our youth, and wakened us from sleeping, With hand made sure, clear eye, and sharpened power,

To turn, as swimmers into cleanness leaping,

Glad from a world grown old and cold and weary, Leave the sick hearts that honour could not move, And half-men, and their dirty songs and dreary, And all the little emptiness of love!

Oh! we, who have shown shame, we have found release there,

Where there's no ill, no grief, but sleep has mending, Naught broken save this body, lost but breath;

Nothing to shake the laughing heart's long peace there

But only agony, and that has ending;

And the worst friend and enemy is Death.'
}

and the last stanza of 'The Dead', the poem which starts with the line: 'Blow out, you bugles, over the rich Dead', in which he wrote:

'Honour has come back, as a king, to earth, And paid his subjects with a royal wage;

And Nobleness walks in our ways again; And we have come into our heritage.'

It is possible that some of the young men who went to the Falklands saw it as an adventure in that light, and even that some who held a share of the responsibility for sending them there did so; but it is certainly not an attitude that could be thought of as generally accepted today. In 1914 there were large elements of all the participants who thought that way. Nevertheless there is still no lack of enthusiasm for heroes, certainly in the popular media; and the Falklands War showed that sentiments, which many regarded as totally out of date and reminiscent of Victorian jingoism, were not far below the surface.

The remarkable advances that have been made in medicine and surgery, and in the speed of communications, have led people to expect, not only that almost $\vec{\circ}$ every ailment or injury can be quickly cured; that one can receive almost instant attention; that safety precautions should be such that these hazards should be prevented; but also that every citizen has a right to enjoy these benefits, whether or not he or she has contributed to them. I am not implying that this is a development to be deplored. The point I wish to emphasize is that it has changed peoples' attitudes towards what used to be regarded as inevitable hazards of life. Not only does that affect the likely reaction of the individual soldier, sailo or airman to the hazards of war; but taken together with the presence of television and radio reporting from the battlefield, it powerfully affects the attitude of the public, including their relatives and friends. This changs in attitude accentuates, it seems to me, the morat dilemma which faces all military men, and doctors most of all - even more than chaplains. All of us face th 8 problem that we are brought up to believe that the wor of all the crimes against society is to kill another huma being. Yet we have chosen, or in the case of conscripte soldiers, have been obliged, to become professional killers. For the military doctor the dilemma is even greater. His primary profession demands that he must do everything to preserve the human body, and the mind it incorporates, in as near perfect working order as he can. The greater the value which society attaches to the preservation of life, and its perfect working order, and the higher society's expectations of that being achieved, the greater the conflict between the demands made on the military doctor by his dual professional loyalties. Unlike the chaplain, he is not just there in order to mitigate the effects of war on the participants, although his contribution to that end is vital. But, whether it is in the field of preventive medicine or in the treatment of casualties, physical or psychiatric, he is also expected to contribute to the more effective use of manpower - to see that the cannon is well supplied with fodder in good condition. The memoirs of regimental medical officers, particularly in the First World War, emphasize the strain that this conflict of loyalties imposed on them. Those of Lord Moran, in his book, The Anatomy of Courage, are among the best known and most eloquent. 
Let us therefore look at the different fields in which the military doctor makes his contribution. I use "military" in its general sense of applying to all three services. Let us see what changes have taken place and how they are likely to affect the task of the military doctor in the future. I will consider them in the order in which they would apply to the patient.

\section{Selecting the Recruit}

In the important field of selection, until very recently, the doctor's contribution to this was limited to purely physical characteristics such as height, weight, freedom from disease, sight, hearing, and such interesting matters as whether or not the would-be recruit had at least seven teeth functionally opposed. Other nonmedical tests have been gradually introduced: of education and general intelligence, of manual dexterity and aptitude for the speciality which the recruit aspires to, and, in the case of officer selection, of leadership qualities. Only very recently, and I do not myself know to what extent, has the psychiatrist been involved in trying to detect whether or not the man, whatever his educational or physical standards, is likely to be able to stand up to the stresses of war.

The application of medical skill to selection is much simpler in the case of voluntary service, when the forces are able to reject recruits without difficult implications. Even then, problems begin to arise when the services are finding it difficult to recruit men and women in the numbers and up to the standards they require. When conscription is applied, the problem becomes complicated by the question of exemption from service on medical, and particularly on psychiatric grounds.

Enormous changes have taken place in the whole field of development of the recruit, perhaps from a pale, weedy youth, brought up on unhealthy foods, into a strong, healthy, fit soldier, capable of considerable feats of physical endurance and of looking after himself sensibly. Preventive medicine in all its aspects nutrition, clothing, and a scientific approach to physical exercise and well-being - have all played their part, so that disease is no longer the major killer of soldiers, as it had been up to the First World War. As a member of the Council of the Cancer Research Campaign, I wish that the campaign against smoking could make further inroads in this field, but $I$ recognize that the life of a soldier, in peace and war, is one that inevitably attracts resort to tobacco as an antidote to boredom or stress; and better tobacco I suppose, than to abuse of drugs of any kind.

\section{Training in First Aid}

Training in first aid is an important part of the contribution of the medical services to the soldier's general training. Most soldiers - I cannot speak for sailors and airmen - are now better trained and more confident than they were decades ago, that they could render first aid to an injured comrade, and what they can do has been extended. Some may say there is a danger that they may attempt too much. I am reminded of a stern reproof I got from the doctor at the field dressing station to which my scout-car driver was taken, after he had lost a foot when we were blown up on a mine, because I had given him a morphine injection. I had to remove the steering wheel before I could get him out, which took some time, and he had begged me to do so.

\section{Morale}

It is when we come to the battlefield, or whatever form active operations may take, that the doctor's problem of conflicting loyalties begins to sharpen, although treating wounded is primarily a matter of medical judgement. The problems may be difficult, but probably do not pose a clash of loyalties, unless the number of casualties is so great that he has to make the decision not to devote effort to those whom he judges to have little chance of recovery - the selection process known as triage. The advances made both in surgery itself and in the general treatment of injuries, and with the use of the helicopter, the speed and smoothness of evacuation have produced a revolution in what the wounded on the battlefield can expect - as the Falklands war demonstrated. That makes a tremendous contribution? to the morale of the fighting man. All those who have studied that subject - and much has now been written about it - agree that soldiers fear wounds more than theyo do death, about which they tend to be fatalistic. Confidence that, if wounded, they will be quickly evacuated and effectively treated, removes or reduces a great deal of that anxiety, and supports the fighting spirit which is the key to success on the battlefield. The changes that have come about in this field, therefore, make the task of the military doctor easier than it used to be, and ought to relieve the pressure on him. But there is another side to that coin. We have come to expect high standards, and because the operations in which we have been engaged, since at least the Korean War, have been on such a small scale, and, when the fighting has been intense, it has been of such short duration, we have generally been able to maintain these standards both of evacuation and of treatment. But, leaving aside for the moment the question of nuclear and chemical weapons, it is at least arguable whether those standards, particularly of evacuation, could be maintained in the event of a war in Central Europe. The dismay of all concerned, both of the combat soldiers and the doctors, if that proved to be the case, could pose serious problems of morale.

\section{Moral Fibre and Battle Exhaustion}

Mention of morale brings me to what I see as the principal problem. Battle casualties include not only physical injury, but also injury of the mind. The general public may not be aware of the high proportion of 
psychiatric casualties in intense periods of fighting in the Second World War. In the British Second Army in North West Europe, they started as $10 \%$ of all casualties evacuated behind units from D Day until the end of June 1944 , rose to $20 \%$ until the Battle of Normandy was over in August, and then fell to $14 \%$ until the end of the year, when they dropped to $10 \%$ and finally to $8 \%$ after we had crossed the Rhine.

In the US Army the rate was generally higher, a peak of $54 \%$ being reached in the US 2 nd Armoured Division in 44 days of sustained operations in Italy.

The problem of the attitude which military commanders and their doctors take to soldiers who break down, or just deteriorate, under the stress of battle - or the anticipation of it, or the after-effects of it - is one which poses the conflict of loyalties at its keenest, both for the commander and for the doctor. Both have to balance, on the one hand, the requirements for the effective prosecution of the war or the battle, linked to the morale both of the unit and of the army as a whole, against, on the other hand, the human needs of the individual. The military professional element demands that the individual must be sacrificed to the greater cause, and the medical, that every individual human being has the same right to receive the best professional service that the doctor can give, even the enemy.

The contrast is most extreme when one compares general attitudes between the First World War and the present day. Even if one does not go as far back as that, but only to the Second World War, most of those who took part had been brought up to think that fear was something one must not admit to, and, indeed, that one should not give way to, nor openly express any of one's emotions, even good ones like love or appreciation of one's fellow men and women. It was unmanly to do so. With that, went the concept that one is capable of controlling one's emotions if one exercised the willpower to do so, and that that was the right thing to do. There was no excuse therefore for giving way to fear, and one should not admit that one felt it. There is a great deal of evidence to show that one of the greatest fears that soldiers have, and no doubt sailors and flying airmen too, is how they will show up under fire. The fear that they may show their fear, and not be able to control it, is all the greater if the current ethos is that it is cowardly to admit to it.

The current social ethos is almost exactly the opposite, although fortunately it is limited in practice. The tenets of the aesthetic movement, of which Oscar Wilde was one of the leaders at the end of the 19th century, that it is wrong to repress one's instincts or emotions, and that life should be lived to the full by giving full rein to them, have taken hold. The classic psychologists bear some responsibility for that. One sees the results today in many aspects of life, from the sporting arena to the non-marital bed. A great deal of it must be welcomed. It has largely removed that terrible sense of guilt and sin, which was such an oppressive aspect of Victorian values. But, although it has removed some sources of unhappiness, it has created others, and it poses problems for a profession which must be based on the need to sacrifice individual interest for what is seen as the interest of the community of which the individual is a member. The problem is magnified by the fact that, with very few exceptions, nobody, from the Army Group Commander down to the private soldier, will have had any experience of battle.

The extreme version of the old ethos in the First World War had some tragic consequences. The conditions under which soldiers served, whether in the massive and prolonged offensives, or during the long periods in flooded trenches in between, imposed the severest stress. The combination of the accepted ethos towards any sign of weakness, and the unimaginative attitude of the higher command and of a considerable proportion of the medical services, had unfortunate results. One was in selection, or the lack of it. Whether the man was originally a volunteer or a conscript, no attempt was made to identify and reject those whose character or background made it likely that they would be unable to stand up to the stresses of the battlefield. Any suggestion that a man would not be able to, of having got there, could not stand up to them, would, the authorities believed, not only threaten the availability of manpower, but would undermine discipline and the resolution of other soldiers. It would also be unfair of $\mathbb{D}$ others to allow some to escape the trials to which theif comrades were subjected.

\section{The death penalty for the 'sake of example'}

On the battlefield this assumed a greater significance No excuse could be accepted for not 'going over the top? when ordered, or for attempting to escape, by some means or other, the dangers and discomforts of the front-line trench. One way out was to 'go sick', which placed the onus of decision on the regimental medical officer. If there was no sign of a recognized ailment, or even if there was and it wasn't serious, he had to decide whether to send the patient forward again or back to the rear. If he did the former, the man, knowing that he couldn't go sick again, either went over the top in a state perhaps of nervous prostration, or refused, or deserted, in which case he was liable to a field court-martial, followed by a firing squad. Either probably ended in death. In that war, 245 soldiers were executed in that way for desertion, 17 for cowardice and 20 for similar offences. The story of the trials, written by Judge Anthony Babington, in his book For the Sake of Example makes grim reading. The trials were perfunctory. The medical evidence, not asked for until after conviction, was generally restricted to whether or not the culprit was of sound mind, or suffering from some recognized malady. In a very large number of cases the court and the intermediate authorities - the brigade, 
divisional and, occasionally, corps commanders - made a recommendation for mercy, but the implacable army commanders and the Commander-in-Chief, Haig, who had to confirm the sentences, followed the principle of Frederick the Great, 'The common soldier must fear his officer more than the enemy', and that of General Wolfe's regimental orders when he commanded the 20th Foot in 1755, 'A soldier who quits his rank, or offers to flag, is instantly to be put to death by the officer or sergeant in rear of that platoon: a soldier does not deserve to live who will not fight for his King and country.'

In that spirit, the army commander of a private soldier, sentenced to death for cowardice in the Battle of the Somme, overruling the recommendations for mercy of all his superior officers up to and including the corps commander, wrote on the proceedings, as he recommended confirmation of the sentence by the C-in-C, 'If toleration be shown to private soldiers who deliberately decline to face danger, all the qualities which we desire would be debased and degraded'.

That particular soldier had been in action continuously for more than three weeks. In the early hours of a moonlit morning he had disobeyed an order from his platoon commander to crawl to a listening-post 40 yards into no-man's land and some 150 yards from the German front line. The post was in a clump of long grass and he would have had to lie motionless in it for an hour. His refusal had been respectful but adamant. He had told the officer that he was not feeling well and that his nerves were in a bad state. He said that, if he went out, he would only be a danger to other men as well as to himself. It was mentioned at his trial two weeks later that his father had been killed in action earlier in the war and that he was constantly worried about his mother, who was looking after six young children.

But the army commander's recomendation was confirmed, and that young man was one of those who, tied to a chair, was shot by a firing squad, usually within two weeks of confirmation of his sentence.

The harsh remedy just described had almost died out of the British Army, until the combination of the conditions of trench warfare and the influx of large numbers of wartime soldiers persuaded the army hierarchy that it was a necessary long-stop to the maintenance of discipline on the battlefield. There had not been a death sentence inflicted for desertion between 1803 and 1901, when Kitchener confirmed one in the Boer War. Before flogging was abolished in 1881, the fear of the lash was considered sufficient, and the fact that the French Army tended to inflict death sentences for offences, which the British punished by flogging, was used as an argument by those who opposed abolition of the lash. But both in the Crimea and in the Boer War, with the one exception mentioned, offences like desertion, absence without leave, disobedience, sleeping on post or quitting it, insubordination or striking a superior, were punished by terms of detention or imprisonment. In the First World War they could, and in some cases did, carry the death penalty.

\section{'Shellshock' and the abolition of the death penalty}

But there was a way out, and in the vast majority of cases it was taken. The key to it was held by the regimental medical officer, and it was labelled shellshock, supposed to have been caused by the concussion of an explosion. As the Southborough Committee, set up in 1920 to inquire into it, concluded, the term had been a 'gross and costly misnomer' covering three classes of nervous disorder - genuine concussion, which was much in the minority, emotional shock and nervous exhaustion. The fact that the death penalty had been used to deal with cases that could have had their origin in one of these disorders led to its abolition in 1930 for all military offences, other than treachery and mutiny. That was against the advice of the Army Council of the time, and of wartime commanders then in the House of Lords, such as Allenby, who said, 'I say most emphatically that in my opinion penal servitude is not a deterrent. It means safety. The only deterrent for the man who will wilfully behave in such a way as to endanger the lives of his own comrades, in order to avoide the risk to his own life, is the knowledge that, while hisc comrades may possibly incur death at the hands of the enemy, which will be a glorious and honourable death, he, if convicted of one of these offences by a courtmartial and executed, will die a death which is dishonourable and shameful.'

Did the Second World War prove him wrong? There are those who will answer 'No' to that question, and point to the high rates of psychiatric casualties in Normandy and to the serious problems of morale including a high rate of desertion, in the last winter of the war in Italy, which prompted some people at the time to demand the return of the death penalty. But there are others, including myself, whose answer is 'Yes'. I would draw your attention to a remarkable short book by Colonel Elmar Dinter, who was a German army student at our own staff college a few years ago, called Hero or Coward. Inspired by the Staff College study 'Stress in Battle' (which they have now, I am glad to say, re-named 'Morale in Battle'), he carried out an extensive review of all the literature on the subject, most of which is American, but which includes General Frank Richardson's book Fighting Spirit. He studied three World War II actions in detail - the British defence of Calais in 1940, the Sixth German Army surrounded at Stalingrad at the end of 1942, and both the German defence of and the Allied attacks on Monte Cassino in 1944. One of the major conclusions he reaches is that the positive factors encouraging a soldier to fight on, even against apparently hopeless odds, outweigh the negative factors tending to push him in the other direction and put first his personal safety or submit to his personal fears and emotions. 


\section{Positive factors and action}

The maintenance of close emotional links between comrades ranks high among these positive factors, reinforced by belief in his outfit's superiority over others, and his pride in that, including his personal pride in being a worthy member of it. The maintenance of hope in the future is another important factor. The knowledge that there will be some relief from the conditions he is enduring is important. These two factors can operate against each other. Rotations and reliefs are important, but, if carried out on an individual basis, they destroy group cohesion. Inactivity and the inability to do anything about it, particularly if prolonged, saps morale. Any activity, however pointless, helps to keep it up. Sleep, food and drink are essential foundations. If deprived of them, particularly of sleep, the man can deteriorate until he becomes a psychiatric casualty, and has to be treated as such. The earlier the need for rest can be detected and met, the less the likelihood of deterioration. Sleep is itself a form of psychiatric treatment. The more the exhausted man can be kept in or near his unit, and returned to it rested and restored, the better for him and everyone else.

There is a longer-term form of battle exhaustion, which is the one I found myself having to deal with most when I was a commanding officer, and especially when I was a brigade commander in World War Two. The man, who had a splendid record, had been through several campaigns and wore medals for bravery with pride, but whose capital in the balance of courage and determination had been spent. He was reluctant to recognize it, and his comrades and subordinates were too loyal to him to let his superiors know.

In all these cases, the medical officer has a very important part to play. To spot the symptoms, to treat them by the simple methods, such as rest, which will prevent them turning into a psychiatric problem, and to persuade the commander at the appropriate level that that is the right thing to do. Mutual trust between the medical officer and the commanding officer is an essential foundation for that. An almost intolerable burden is placed on the former, if the commanding officer himself is the man who needs help, but won't admit it.

As an armoured brigade commander between Normandy and the end of the war, I had to remove four commanding officers, all of them highly decorated and respected men, older than myself and with more experience of battle than I. But they had had it, and for the sake both of their units and of themselves, they had to go. None of their subordinates, nor their RMO's, ever gave me a clue that I should act as I did. They were too loyal. It was my own personal experience of being beside them in battle which made it clear to me. One, who protested violently at the time, wrote to me 20 years later to thank me and say I was right, and the former subordinates of his and of the others, when we have discussed it since, asked me why I had not acted sooner.

My faith in the positive factors makes me accept that, although there will be both bad characters and weak ones, who may try and evade the duty which their comrades are prepared to face, even unto death, we do not need to use the weapon of fear to counter fear. Disgrace, perhaps, but not Frederick the Great's or Wolfe's remedy. If we are to do so, we must pay constant attention to the fostering and maintenance of those positive factors.

\section{New Fears}

The sort of long-term exhaustion I have described is not likely to be a problem if war were to break out in Europe. The psychological problem at all levels would be much more immediate and intense. Dominating the fear of how the individual would react to the unknown would be the fear that nuclear weapons might be used at any moment. Studies of battle morale stress the effect of new and strange weapons. Gas in the First World Wat? air attack and tanks in the Second, had, initially, a much greater psychological than physical effect. When ono T adds the fear of nuclear and/or chemical attack to th $\vec{g}$ lack of experience of the effects of conventiona weapons used in intensity, one can begin to appreciat the psychiatric problems that face the medical services in contemplating such a war. They will be imposed of the physical problems of providing adequate medici care in those circumstances. Can it be done? Anyone who has read the report produced by the Scientific Committee of the British Medical Association some years ago, and the more recent British Medical Association report Selection of casualties for treatment under nuclear attack must have doubts about that. Should the medical authorities pretend that it can? That is one more example of the moral conflict between the loyalties to the two professions to which the medical services of the armed forces owe allegiance. I do not pretend that it is not a very difficult one for your consciences to resolve.

This manuscript is being published simultaneously in the Journal of the Royal Army Medical Corps and the Journal of the Royal Society of Medicine by arrangement with both Editors. 